\title{
Patient-reported outcomes in European spondyloarthritis patients: a systematic review of the literature
}

This article was published in the following Dove Press journal:

Patient Preference and Adherence

\author{
Juan Carlos Torre-Alonso' \\ Rubén Queiro ${ }^{2}$ \\ Marta Comellas ${ }^{3}$ \\ Luís Lizán ${ }^{3,4}$ \\ Carles Blanch ${ }^{5}$ \\ 'Rheumatology Department, Faculty \\ of Medicine and Health Sciences, \\ University of Oviedo, Hospital \\ Monte Naranco, Oviedo, Spain; \\ ${ }^{2}$ Rheumatology Division, Hospital \\ Universitario Central de Asturias \\ (HUCA), Oviedo, Spain; ${ }^{3}$ Outcomes \\ 10, Castellón de la Plana, Spain; \\ ${ }^{4}$ Medicine Department, Jaime I \\ University, Castellón de la Plana, \\ Spain; ${ }^{5}$ Health Economics \& Market \\ Access, Novartis Pharmaceuticals, \\ Barcelona, Spain
}

Objective: This review aims to summarize the current literature on patient-reported outcomes (PROs) in spondyloarthritis (SpA).

Patients and methods: We performed a systematic literature review to identify studies (original articles and narrative and systematic reviews) regarding PROs (health-related quality of life [HRQoL], satisfaction, preferences, adherence/compliance, and persistence) in SpA patients published in the European Union through December 2016. International databases (Medline/ PubMed, Cochrane Library, ISI Web of Knowledge, Scopus) were searched using keywords in English. The methodological quality of the studies was assessed using the Oxford Centre for Evidence-Based Medicine criteria.

Results: A total of 26 publications met the inclusion criteria. Generally, studies indicated that SpA has a negative impact on patients' HRQoL. In patients with ankylosing spondylitis, physical domains were more affected than emotional ones, whereas for psoriatic arthritis, both physical and psychological factors were strongly affected by the disease. Data indicated that biological agents (BAs) greatly contributed to improvement in HRQoL in both ankylosing spondylitis and psoriatic arthritis patients. Findings on compliance with BAs were heterogeneous. However, persistence rates exceeded 50\% irrespective of the BA administered. Results on preferences indicated that most SpA patients prefer being involved in decisions regarding their treatment and that besides efficacy and safety, frequency and route of administration may influence patients' preferences for BAs.

Conclusion: Implementing management programs for SpA patients focuses on the physical, emotional, and social consequences of the disease, in addition to assessing and including patient preferences in the treatment decision-making process, could be crucial to improve patients' HRQoL and ensure their satisfaction and compliance with treatment.

Keywords: spondyloarthritis, ankylosing spondylitis, psoriatic arthritis, patient-reported outcomes, European Union, systematic review

\section{Introduction}

Spondyloarthritis (SpA) refers to a group of interrelated inflammatory diseases that share some features, including articular and extra-articular manifestations. ${ }^{1}$ SpA affects $1 \%-3 \%$ of the general population. In European countries, the reported prevalence varies between $0.3 \%$ and $1.9 \%{ }^{2}$ Ankylosing spondylitis (AS) and psoriatic arthritis (PsA) are the most frequent types of SpA. AS mainly affects the spine and sacroiliac joint and to a lesser extent the peripheral joints and entheses. PsA is characterized by the involvement of both peripheral and/or spinal joints and skin manifestations. ${ }^{2,3}$ The European prevalence of AS is $0.03 \%-1.8 \%$, while prevalence is $0.05 \%-0.42 \%$ for PsA. ${ }^{4}$

\footnotetext{
Correspondence: Juan Carlos

Torre-Alonso

Facultad de Medicina y Ciencias de la Salud, Reumatología Hospital Universitario Monte Naranco, 107 Avenida Doctores Fernández Vega, Oviedo, Asturias 33012, Spain

Tel +34985106900

Email jctorre@telecable.es
} 
PsA causes joint damage that leads to loss of articular function; specifically, a high percentage of PsA patients have more than one deformed joint and about $20 \%$ develop a very destructive disabling form of arthritis. ${ }^{5}$ As a consequence, progression of PsA leads to a reduction in patients' functional capacity, affecting their social and working lives. ${ }^{6}$ Various studies have suggested that $\mathrm{SpA}$ has a negative impact on functional status and patients' health-related quality of life (HRQoL), ${ }^{7-9}$ and it is associated with an increased risk of death. ${ }^{5}$

AS patients typically present axial skeleton and sacroiliac joint involvement, resulting in structural and functional impairment. Additionally, many extra-articular features may also occur in AS patients, including uveitis, osteoporosis, bowel disease, and cardiac, pulmonary, skin (psoriasis), and kidney involvement. ${ }^{10}$ The incidence of cardiovascular disease and mortality is also increased in AS patients. ${ }^{5}$ Adults with AS may thus have significantly reduced HRQoL, in addition to limitations in physical functioning and comorbidities that are strongly associated with decreased work productivity. ${ }^{7}$

In view of the clinical and social implications of SpA, management of SpA patients should aim to prevent structural damage and preserve their functional status, in order to optimize HRQoL. ${ }^{11-13}$ With this aim, new therapies, such as biological therapies, have been developed, and new treatment strategies, eg, treat to target, have been adopted over the last decade. ${ }^{14}$ The implementation in routine-practice of biological agent (BA) therapy ${ }^{11-13}$ has led to a significant improvement in clinical outcomes, including the physical functioning of patients with rheumatic disease.${ }^{15}$ However, poor adherence to medication in SpA patients remains a challenge in clinical practice. ${ }^{16}$ New BAs involve different routes of administration and different toxicity, and are sometimes associated with higher drug costs, all of which may influence patient adherence and preference for medication. ${ }^{17}$ In view of the new scenario, a more patient-centered approach to decision making is needed. In fact, assessing and including patients' preferences within routine clinical practice are related to an increase in medication adherence, as well as improved treatment outcomes. This work reviews and summarizes the current literature on patient-reported outcomes (PROs) in patients with SpA (AS and PsA) in the European Union (EU).

\section{Methods}

We performed a systematic literature review to identify studies on PROs in SpA (AS and PsA) patients. Studies assessing HRQoL, satisfaction, adherence/compliance, or persistence with treatment and patients' preferences for treatment in SpA populations published in the EU through December 2016 were selected. As recommended by the Cochrane Handbook for Systematic Reviews of Interventions, ${ }^{18}$ publicly accessible international databases (Medline/PubMed, Cochrane Library, ISI Web of Knowledge, Scopus) were searched using keywords in English joined by the Boolean operators "OR" and "AND" (Table 1).

\section{Inclusion criteria}

We included original articles, narrative reviews, and systematic reviews in English and Spanish that evaluated PROs (HRQoL, satisfaction, adherence/compliance, or persistence with treatment and patients' preferences) in SpA patients in EU setting.

\section{Exclusion criteria}

We excluded studies conducted in non-EU countries, letters to the editor, editorials, experts' opinions, case studies, congress proceedings, mixed-population studies, those that focused on only one explanatory factor, and studies related to specific medical interventions.

\section{Selection of studies}

Following removal of duplicates and irrelevant publications, two independent researchers screened the remaining studies based on preset inclusion and exclusion criteria. Discrepancies were resolved by consensus. The methodological

Table I Search terms and search strategies

\begin{tabular}{ll}
\hline $\begin{array}{l}\text { Number of } \\
\text { search terms }\end{array}$ & Search terms \\
\hline 1 & Ankylosing spondylitis (MeSH) \\
2 & Ankylosing spondylitis \\
3 & Psoriatic arthritis (MeSH) \\
4 & Psoriatic arthritis \\
5 & Quality of life (MeSH) \\
6 & QoL \\
7 & Health related quality of life \\
8 & HRQoL \\
9 & Medication adherence (MeSH) \\
10 & Patient compliance (MeSH) \\
11 & Medication persistence (MeSH) \\
12 & Adherence \\
13 & Compliance \\
14 & Persistence \\
15 & Satisfaction \\
16 & Preference \\
17 & Utility \\
18 & Utilities \\
\hline & Search strategies \\
\hline & (I OR 2) AND (5 OR 6 OR 7 OR 8) \\
\hline & (3 OR 4) AND (5 OR 6 OR 7 OR 8) \\
\hline & (I OR 2) AND (9 OR I0 OR II OR I2 OR \\
\hline & I3 OR I4 OR I5 OR I6 OR I7 OR I8) \\
\hline & (3 OR 4) AND (9 OR I0 OR II OR I2 OR \\
\hline I3 OR I4 OR I5 OR I6 OR I7 OR I8) \\
\hline
\end{tabular}


quality of the studies was assessed using Oxford Centre for Evidence-Based Medicine criteria. ${ }^{19}$

\section{Results}

\section{Studies selected}

The database searches yielded a total of 8,954 titles. Of these, 8,864 were excluded as irrelevant to study purposes $(4,748$, $53 \%)$ or duplicates $(3,916,43.7 \%)$. Following full-text reading and application of the inclusion/exclusion criteria, 26 of the remaining 290 publications were included in the review (Figure 1). Most publications reviewed ( $n=16,61.5 \%)$ were cross-sectional studies examining HRQoL in SpA patients, while a lower proportion evaluated other PROs such as persistence, satisfaction, or preferences (Table 2).

\section{HRQoL in SpA patients}

Of the 18 publications examining HRQoL in SpA patients, $13(72.5 \%)$ employed generic HRQoL instruments, while only four used disease-specific questionnaires, alone or in combination with generic ones (Tables 2 and 3 ).

\section{HRQoL in SpA patients compared with other} rheumatological disorders and the general population

Salaffi et $\mathrm{al}^{20}$ revealed that inflammatory rheumatic diseases, including SpA, have a negative impact on patients' HRQoL,

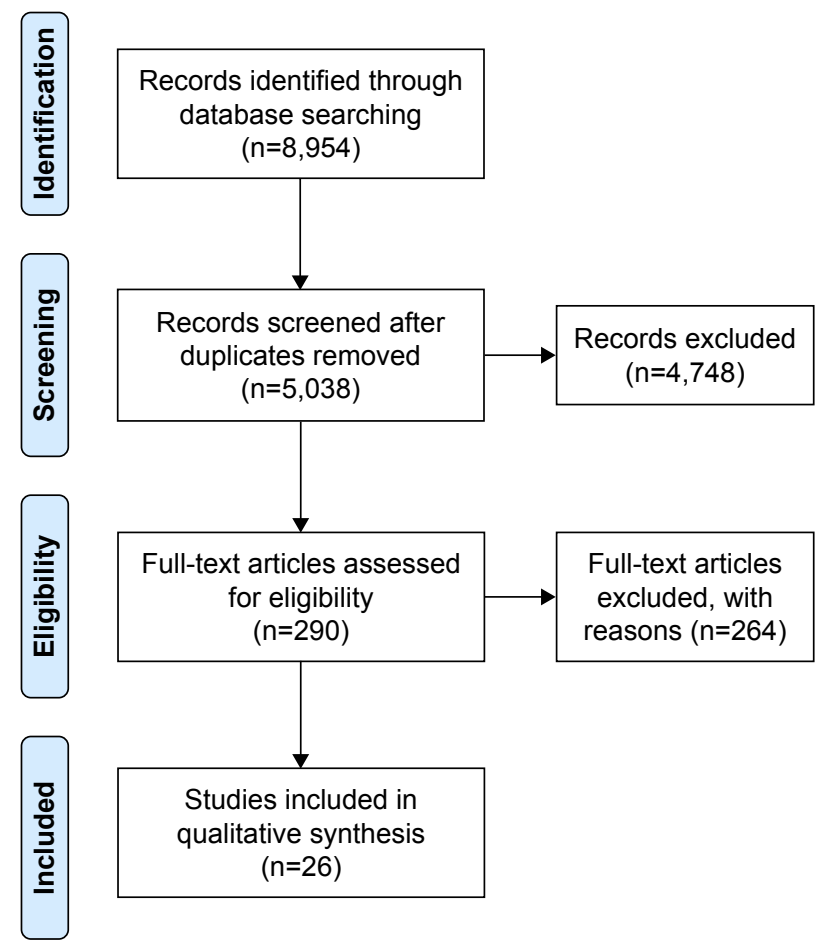

Figure I Flowchart of study selection according to PRISMA. Abbreviation: PRISMA, Preferred Reporting Items for Systematic Reviews and Meta-Analyses. affecting both physical (physical component summary [PCS]) and mental (mental component summary [MCS]) dimensions. PCS was more affected in AS, whereas both physical and emotional well-being deteriorated in patients with PsA.

\section{Correlation between clinical variables and HRQoL} in SpA

Of the studies selected, two ${ }^{20,21}$ sought to identify explanatory clinical factors for HRQoL in SpA. In particular, Salaffi et $\mathrm{al}^{20}$ showed that for inflammatory rheumatic diseases, high disease-activity score, chronic comorbidity, and radiographic damage negatively affected PCS, while the severity of psoriatic lesions (Psoriasis Area and Severity Index) was significantly associated with poor MCS in PsA patients. In the same line, Jajić et $\mathrm{al}^{21}$ observed that for AS patients, clinical variables correlated mainly with PCS, whereas in PsA patients both PCS and MCS were affected by the disease. Functional status, measured by the Bath Ankylosing Spondylitis Functional Index (BASFI), had the strongest impact on PCS in both diseases.

\section{Depression, anxiety, and HRQoL in SpA}

Kotsis et $\mathrm{al}^{22}$ and Hyphantis et $\mathrm{al}^{23}$ investigated the prevalence of major depressive disorders in SpA and rheumatoid arthritis (RA) and their association with HRQoL. Both studies showed that psychological factors were strongly associated with HRQoL in PsA patients. In particular, both anxiety and concern about bodily symptoms were independent correlates of the physical domain of HRQoL. ${ }^{22}$ On the other hand, only cognitive variables were important correlates of HRQoL in AS patients, with illness concern being the only significant independent correlate of physical HRQoL. ${ }^{23}$

\section{HRQoL and work productivity in SpA patients}

Two studies evaluated the relationship between HRQoL and productivity loss in SpA patients. Chorus et $\mathrm{al}^{24}$ showed a positive association between work and HRQoL PCS; however, no association was found with MCS. Kawalec et $\mathrm{al}^{25}$ observed that patients' HRQoL, expressed as utility scores, was negatively correlated with absenteeism, presenteeism, and indirect costs, suggesting that higher HRQoL was associated with higher productivity and lower indirect costs. Disease-activity score was positively correlated with indirect costs and negatively correlated with HRQoL. Therefore, the greater the disease activity, the lower the utility and the larger the indirect cost.

\section{Compliance and HRQoL in SpA patients}

Hromadkova et $\mathrm{al}^{26}$ assessed the relationship between drug compliance and HRQoL in patients with different rheumatic 
Table 2 Description of studies reviewed

\begin{tabular}{|c|c|c|c|c|}
\hline & Design & $\begin{array}{l}\text { Evidence } \\
\text { level }\end{array}$ & $\begin{array}{l}\text { PROs } \\
\text { evaluated }\end{array}$ & PROMs used \\
\hline Salaffi et al ${ }^{20}$ (Italy) & Cross-sectional & $2 \mathrm{C}$ & HRQoL & SF36 \\
\hline Jajić et al ${ }^{21}$ (Croatia) & Cross-sectional & $2 \mathrm{C}$ & HRQoL & SF36 \\
\hline Kotsis et $\mathrm{al}^{22}$ (Greece) & Cross-sectional & $2 \mathrm{C}$ & HRQoL & WHOQoL-Bref \\
\hline Hyphantis et $\mathrm{al}^{23}$ (Greece) & Cross-sectional & $2 \mathrm{C}$ & HRQoL & WHOQoL-Bref \\
\hline Chorus et $\mathrm{al}^{24}$ (the Netherlands) & Cross-sectional & $2 \mathrm{C}$ & HRQoL & SF36 \\
\hline Kawalec et $\mathrm{al}^{25}$ (Poland) & Cross-sectional & $2 \mathrm{C}$ & HRQoL & EQ5D \\
\hline Saad et $\mathrm{al}^{27}$ (UK) & $\begin{array}{l}\text { Prospective study } \\
\text { (6-month follow-up) }\end{array}$ & $2 B$ & HRQoL & Ad hoc questionnaire \\
\hline $\begin{array}{l}\text { Sieper et al }{ }^{28} \text { (Germany, } \\
\text { France, Spain, Italy, UK) }\end{array}$ & Cross-sectional & $2 \mathrm{C}$ & HRQoL & $\begin{array}{l}\text { SF36 } \\
\text { EQ5D }\end{array}$ \\
\hline Kucharz et al ${ }^{30}$ (Poland) & Cross-sectional & $2 \mathrm{C}$ & HRQoL & SF36 \\
\hline Ariza-Ariza et al ${ }^{31}$ (Spain) & Cross-sectional & $2 \mathrm{C}$ & HRQoL & EQ5D \\
\hline de las Peñas et al ${ }^{32}$ (Spain) & Cross-sectional & $2 \mathrm{C}$ & HRQoL & ASQoL \\
\hline Ariza-Ariza et $\mathrm{al}^{33}$ (Spain) & Cross-sectional & $2 \mathrm{C}$ & HRQoL & EQ5D \\
\hline O’Dwyer et al ${ }^{34}$ (Ireland) & Cross-sectional & $2 \mathrm{C}$ & HRQoL & $\begin{array}{l}\text { PsAIDI } 2 \\
\text { DLQI } \\
\text { EQ5D } \\
\text { SF36 }\end{array}$ \\
\hline $\begin{array}{l}\text { Tälli et al }\left.\right|^{35} \text { (multicenter - } \\
\mid 3 \text { countries) }\end{array}$ & Cross-sectional & $2 \mathrm{C}$ & HRQoL & PsAIDI 2 \\
\hline $\begin{array}{l}\text { Puyraimond-Zemmour et } \mathrm{al}^{36} \\
\text { (multicenter - } 13 \text { countries) }\end{array}$ & Cross-sectional & $2 \mathrm{C}$ & HRQoL & $\begin{array}{l}\text { EQ5D } \\
\text { PsAQoL }\end{array}$ \\
\hline Brodszky et $\mathrm{al}^{37}$ (Hungary) & Cross-sectional & $2 \mathrm{C}$ & HRQoL & SF36 \\
\hline Hromadkova et $\mathrm{al}^{26}$ & Cross-sectional & $2 \mathrm{C}$ & HRQoL & SF36 \\
\hline (Czech Republic) & & & Compliance & CQR \\
\hline Wallman et $\mathrm{al}^{29}$ (Sweden) & Prospective (3-year follow-up) & $\mathrm{IC}$ & $\begin{array}{l}\text { HRQoL } \\
\text { Persistence }\end{array}$ & $\begin{array}{l}\text { EQ5D } \\
\text { Kaplan-Meier curves }\end{array}$ \\
\hline López-González et al ${ }^{39}$ (Spain) & Systematic literature review & $2 \mathrm{~A}$ & $\begin{array}{l}\text { Compliance } \\
\text { Persistence } \\
\end{array}$ & \\
\hline Lyu et $\mathrm{al}^{40}$ (Germany) & Retrospective (12-month follow-up) & $2 \mathrm{~B}$ & Persistence & Kaplan-Meier curves \\
\hline Saad et $\mathrm{al}^{4 !}(\mathrm{UK})$ & Prospective (3-year follow-up) & IB & Persistence & Kaplan-Meier curves \\
\hline Kristensen et al ${ }^{42}$ (Sweden) & Prospective (2-year follow-up) & IB & Persistence & Kaplan-Meier curves \\
\hline Favalli et al ${ }^{43}$ (Italy) & Retrospective (8-year follow-up) & $2 B$ & Persistence & Kaplan-Meier curves \\
\hline Renzi et al ${ }^{44}$ (Italy) & Cross-sectional & $2 \mathrm{C}$ & Satisfaction & Ad hoc questionnaire \\
\hline Nolla et al ${ }^{45}$ (Spain) & Cross-sectional & $2 \mathrm{C}$ & Preferences & Rank-based conjoint analysis \\
\hline Rothery et $\mathrm{al}^{46}$ (UK) & Cross-sectional & $2 \mathrm{C}$ & Preferences & DCE \\
\hline
\end{tabular}

Abbreviations: ASQoL, Ankylosing Spondylitis Quality of Life; CQR, Compliance Questionnaire Rheumatology; DCE, discrete-choice experiment; DLQI, Dermatology Life Quality Index; EQ, EuroQol; HRQoL, Health-Related Quality of Life; PsAID, Psoriatic Arthritis Impact of Disease; SF, Short Form; WHOQoL-Bref, World Health Organization Quality of Life - brief.

disorders, including SpA. A significantly negative correlation between compliance and HRQoL PCS was found in SpA patients, suggesting that patients with worse HRQoL might be more compliant with treatment.

\section{Influence of biological therapies on SpA-patient HRQoL}

Three of the studies investigated the impact of BAs on HRQoL in SpA patients in the clinical practice setting. Saad et $\mathrm{a}^{27}$ reported a significant improvement in all Short Form (SF)-36 subscales after 6 months of therapy with BAs, with greatest improvements observed in PCS. Sieper et $\mathrm{al}^{28}$ found that in nonradiographic axial SpA (nr-axSpA) patients, treatment with BAs was associated with improved clinical outcomes (pain, remission, acute episodes) compared to BA-naïve patients. Furthermore, BA-naïve patients reported greater presenteeism, overall work impairment, and activity impairment than BA-treated patients. In line with previous studies, Wallman et $\mathrm{al}^{29}$ showed that following BA treatment, both HRQoL (EuroQoL 5D utility and visual analog scale) and clinical outcomes (pain, erythrocyte-sedimentation rate and CRP) improved rapidly in both nr-axSpA and AS patients.

\section{HRQoL in AS patients}

\section{Factors influencing HRQoL in AS patients}

Kucharz et al ${ }^{30}$ observed that almost two-thirds of AS patients considered pain a very important risk factor in their HRQoL. 
Table 3 Characteristics of HRQoL-related studies reviewed

\begin{tabular}{|c|c|c|c|}
\hline & Objective & $\begin{array}{l}\text { Demographic and clinical } \\
\text { characteristics }\end{array}$ & Main results \\
\hline $\begin{array}{l}\text { Salaffi et a }{ }^{20} \\
\text { (Italy) }\end{array}$ & $\begin{array}{l}\text { To compare HRQoL scores } \\
\text { among patients with RA, } \\
\text { PsA, and AS and a selected } \\
\text { sample of healthy people and } \\
\text { determine their relationship } \\
\text { with measures of clinical } \\
\text { condition }\end{array}$ & $\begin{array}{l}\text { RA ( } n=469,71.8 \% \text { female, mean age } \\
57.5[S D \text { I4.3] years, disease duration } \\
6.1 \text { [SD 4.2] years) } \\
\text { AS ( } n=164,18.9 \% \text { female, mean age } \\
51.7 \text { [SD 9.2] years, disease duration } \\
8.2 \text { [SD 4.6] years) } \\
\text { Axial PsA ( } n=65,50.7 \% \text { female, mean } \\
\text { age } 58.2 \text { [SD I0.3] years, disease } \\
\text { duration } 8.4 \text { [SD 4.3] years) } \\
\text { Peripheral PsA ( } n=101,61.4 \% \text { female, } \\
\text { mean age } 60.7 \text { [SD II.6] years, disease } \\
\text { duration } 7.5 \text { [5.3] years) } \\
\text { General population ( } n=I, 579,50.2 \% \\
\text { female, mean age } 55.2[S D \text { I9.2] years) }\end{array}$ & 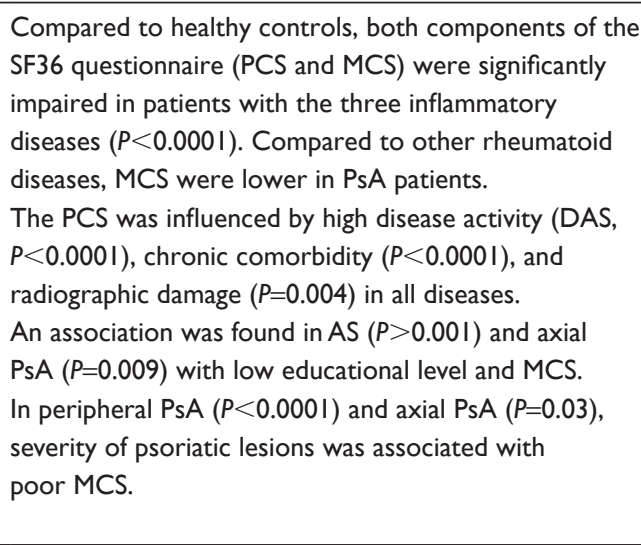 \\
\hline $\begin{array}{l}\text { Jajić et al }{ }^{2 !} \\
\text { (Croatia) }\end{array}$ & $\begin{array}{l}\text { To assess clinical } \\
\text { variables with the best } \\
\text { correlation with HRQoL } \\
\text { in patients with } \mathrm{SpA}\end{array}$ & $\begin{array}{l}\text { AS }(n=32,62.5 \% \text { female, mean age } \\
51.4[S D 9.7] \text { years, disease duration } \\
7[2-11] \text { years }) \\
\text { PsA ( } n=22,50 \% \text { female, mean age } 54.2 \\
{[S D 8.3] \text { years, disease duration } 10.5} \\
[4-12] \text { years })\end{array}$ & $\begin{array}{l}\text { Although perception of general health was similar in } \\
\text { both groups, AS patients had reduced HRQoL values } \\
\text { for physical domains, whereas PsA patients presented } \\
\text { reduced HRQoL values for both PCS and MCS. } \\
\text { For AS patients, clinical variables correlated mainly with } \\
\text { the PCS, while in PsA patients correlations between } \\
\text { clinical variables and SF36 were more distributed. } \\
\text { In both diseases, BASFI had the strongest correlation } \\
\text { with PCS. }\end{array}$ \\
\hline $\begin{array}{l}\text { Kotsis et } \mathrm{a}^{22} \\
\text { (Greece) }\end{array}$ & $\begin{array}{l}\text { To compare psychological } \\
\text { distress in PsA and RA and } \\
\text { test whether the association } \\
\text { between psychological } \\
\text { variables and HRQoL was } \\
\text { similar in the two forms of } \\
\text { arthritis }\end{array}$ & $\begin{array}{l}\text { PsA ( } n=83,47 \% \text { female, mean age } \\
48.9 \text { [SD I2.4] years, disease duration } \\
9.2 \text { [SD 6] years) } \\
\text { RA ( } n=199,82.4 \% \text { female, mean age } \\
55.2 \text { [SD 12.7] years, disease duration } \\
\text { 13.7 [SD 10.5] years) }\end{array}$ & $\begin{array}{l}\text { The prevalence of moderate and severe levels of } \\
\text { depressive symptoms (PHQ } 9 \geq 10 \text { ) was similar in PsA } \\
(21.7 \%) \text { and RA ( } 25.1 \%) \text { patients. } \\
\text { Among PsA patients, depression symptoms were more } \\
\text { frequent in those with polyarthritis ( } 36.7 \%) \text { compared } \\
\text { to those with oligoarthritis }(9.8 \%) \text { and spondyloarthritis } \\
\text { ( } 16.7 \%) \text {. } \\
\text { In general, all participants perceived their arthritis as a } \\
\text { chronic disease that could not be controlled. } \\
\text { According to a regression analysis, both anxiety } \\
(\beta=-0.28) \text { and concern about bodily symptoms } \\
(\beta=-0.33) \text { were independent correlates of the physical } \\
\text { domain of HRQoL in PsA patients. }\end{array}$ \\
\hline $\begin{array}{l}\text { Hyphantis et al }{ }^{23} \\
\text { (Greece) }\end{array}$ & $\begin{array}{l}\text { To compare psychological } \\
\text { distress symptoms and } \\
\text { illness perceptions in AS and } \\
\text { RA and test whether their } \\
\text { association with HRQoL } \\
\text { was similar }\end{array}$ & 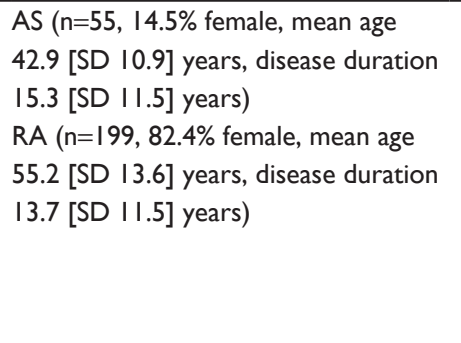 & $\begin{array}{l}\text { The prevalence of clinically significant depressive } \\
\text { symptoms (PHQ } 9 \geq 10 \text { ) was lower in AS ( } 14.8 \%) \\
\text { compared to RA ( } 25.1 \% \text { ) patients }(P=0.09) \text {, but } \\
\text { psychological distress levels and HRQoL were similar in } \\
\text { both disorders. } \\
\text { Illness concern ( } \beta=-0.37 \text { ) was the only significant } \\
\text { independent correlate of physical HRQoL in AS. } \\
\text { Symptoms of anxiety and depression had a minor } \\
\text { contribution to physical HRQoL. }\end{array}$ \\
\hline $\begin{array}{l}\text { Chorus et al }{ }^{24} \\
\text { (the Netherlands) }\end{array}$ & $\begin{array}{l}\text { To investigate the } \\
\text { relationship between work } \\
\text { and HRQoL in patients with } \\
\text { RA and AS aged } 16-59 \text { years }\end{array}$ & $\begin{array}{l}\text { AS ( } n=658,29.9 \% \text { female, mean age } \\
43.5 \text { [SD 9.4] years, disease duration } \\
\text { I2.3 [SD 8] years) } \\
\text { RA ( } n=1,056,72.3 \% \text { female, mean age } \\
49 \text { [SD 8.3] years, disease duration } \\
\text { II.9 [SD 9.1] years) }\end{array}$ & $\begin{array}{l}\text { PCS was worse in patients with RA than AS, although } \\
\text { MCS was reported to be more favorable in RA } \\
\text { than AS. } \\
\text { A positive association between work and PCS in } \\
\text { both group of patients was assessed. However, no } \\
\text { association between work and MCS was fond. }\end{array}$ \\
\hline $\begin{array}{l}\text { Kawalec et al }{ }^{25} \\
\text { (Poland) }\end{array}$ & $\begin{array}{l}\text { To investigate associations } \\
\text { among activity, utility of } \\
\text { PsA-affected patients, and } \\
\text { productivity loss }\end{array}$ & $\begin{array}{l}\text { PsA }(n=50,58 \% \text { female, mean age } 45.5 \\
{[35.75-53.5] \text { years, age at onset } 36.5} \\
[29-44] \text { years })\end{array}$ & $\begin{array}{l}\text { PsA has been demonstrated to reduce patients' HRQoL } \\
\text { and generate considerable indirect costs, mainly due to } \\
\text { lower productivity at work. }\end{array}$ \\
\hline
\end{tabular}


Table 3 (Continued)

\begin{tabular}{lll}
\hline Objective & $\begin{array}{l}\text { Demographic and clinical Main results } \\
\text { characteristics }\end{array}$ & Matin \\
\hline
\end{tabular}

Patients' HRQoL, expressed as utility, was correlated with absenteeism $(-0.537, P=0.002)$ and presenteeism $(-0.682, P<0.001)$. Utility showed a significantly negative moderate-strong correlation with absenteeism, presenteeism, and total indirect cost $(-0.772, P<0.00 \mathrm{I})$. Disease activity was significantly correlated with indirect cost (absenteeism 0.618, presenteeism 0.838, total cost $0.864, P<0.000 \mathrm{I})$ and HRQoL $(-0.878, P<0.000 \mathrm{I})$.

\begin{tabular}{|c|c|c|}
\hline $\begin{array}{l}\text { Hromadkova } \\
\text { et } \mathrm{al}^{26} \text { (Czech }\end{array}$ & $\begin{array}{l}\text { To elucidate the relationship } \\
\text { between drug compliance }\end{array}$ & $\begin{array}{l}\text { SpA }(n=41,68.1 \% \text { female, mean age } \\
50[22-79] \text { years, disease duration }\end{array}$ \\
\hline \multirow[t]{10}{*}{ Republic) } & and HRQoL in patients & $3.8[0.7-8.3]$ years) \\
\hline & with different rheumatic & RA ( $n=178,78.7 \%$ female, mean age \\
\hline & disorders & 59 [26-82] years, disease duration \\
\hline & & $7.4[0.5-19.9]$ years $)$ \\
\hline & & SSc $(n=4 I, 75.6 \%$ female, mean age \\
\hline & & 58 [26-80] years, disease duration \\
\hline & & $6.8[0.5-23.9]$ years $)$ \\
\hline & & JIA $(n=23,73.9 \%$ female, mean age \\
\hline & & $28[|8-5|]$ years, disease duration \\
\hline & & $6.8[0.6-20.9]$ years $)$ \\
\hline \multirow[t]{3}{*}{ Saad et $\mathrm{al}^{27}$ (UK) } & To evaluate the impact of & PsA ( $n=596,52.3 \%$ female, mean age \\
\hline & BAs on HRQoL, functional & 45.7 [SD II.I] years, disease duration \\
\hline & status in PsA patients, and & I2.4 [SD 8.7] years) \\
\hline
\end{tabular}

A significantly negative correlation between compliance and PCS was established in SpA patients $(-0.30 \mathrm{I}, \mathrm{P}<0.05)$. for HRQoL

\begin{tabular}{lll}
\hline Sieper et al ${ }^{28}$ & To assess the impact of & axSpA (n=63I, 29.6\% female, mean age \\
(Germany, & nr-axSpA on patients and & 41.8 [SD I2] years, disease duration \\
France, Spain, & society based on real-world & 51.6 [SD 60] months, cDMARD, \\
Italy, UK) & evidence from the Adelphi & $25.58 \%$, BAs 36.1\%, 66.5\% responders \\
& Disease Specific Programme & to treatment, 24.8\% nonresponders)
\end{tabular}
The largest changes were achieved within the first 6 months of BA treatment, and were sustained throughout the follow-up period (I 8 months). At 6 months, improvement for PCS was 53.2\% (95\% Cl $44.5 \%-61.9 \%)$, whereas for the mental component scale it was $16.9 \%(95 \% \mathrm{Cl} 14.7 \%-19.2 \%)$. There was a statistically significant association between improvement in PCS and change in DAS28 ( $\beta=2.92$ per unit improvement, 95\% Cl 2.10-3.75).

EQ5D utility scores were lower in patients with nr-axSpA versus general population-matched controls ( 0.776 vs $0.884, P<0.00 \mathrm{I})$. Pain-score reduction was higher in BA-treated than BA-naive $(2.5$ vs $4.0, P<0.001)$ patients.

BA-treated patients were more likely to be in remission than BA-naive patients (67\% vs $34 \%, P<0.00$ I). BAs-naive patients reported greater presenteeism ( $28 \%$ vs $16 \%, P=0.037$ ), overall work impairment $(37 \%$ vs $19 \%, P=0.018)$, and activity impairment ( $31 \%$ vs $23 \%$, $P=0.045)$ than BA-treated patients.

\begin{tabular}{|c|c|c|c|}
\hline $\begin{array}{l}\text { Wallman et } \mathrm{al}^{29} \\
\text { (Sweden) }\end{array}$ & $\begin{array}{l}\text { To compare clinical } \\
\text { development, HRQoL, } \\
\text { and treatment adherence } \\
\text { between nr-axSpA and AS } \\
\text { patients during } 3 \text { years of } \\
\text { BA in clinical practice }\end{array}$ & $\begin{array}{l}\text { nr-axSpA ( } n=86,38 \% \text { female, mean } \\
\text { age } 38 \text { [SD I3] years, disease duration } \\
9 \text { [SD 9] years) } \\
\text { AS ( } n=238,24 \% \text { female, mean age } \\
43 \text { [SD 12] years, disease duration } \\
\text { I6 [SD I2] years) }\end{array}$ & $\begin{array}{l}\text { Following BA initiation, mean VAS global, VAS } \\
\text { pain, EQ5D utility, Evaluator's global, ESR, and } \\
\text { CRP improved rapidly in both groups, and within } \\
3-6 \text { months had reached a plateau, which was then } \\
\text { sustained for } 3 \text { years. }\end{array}$ \\
\hline $\begin{array}{l}\text { Kucharz et } \mathrm{al}^{30} \\
\text { (Poland) }\end{array}$ & $\begin{array}{l}\text { To obtain patients' opinions } \\
\text { on factors associated with } \\
\text { AS that may potentially } \\
\text { influence their HRQoL }\end{array}$ & AS ( $n=53,22.2 \%$ female) & $\begin{array}{l}\text { Patients considered pain ( } 64 \% \text { [0, not important at all } \\
\text { to } 4 \text {, very important], mean score } 3.5) \text {, to need help of } \\
\text { another person for everyday functioning }(52 \%, 3.4) \text { and } \\
\text { impairment in family life }(49 \%, 3.4) \text { very important risk } \\
\text { factors in their HRQoL. } \\
\text { Management of AS, including treatment }(23 \%, 2.5) \text { and } \\
\text { frequent hospitalizations }(7.5 \%, 2.4) \text {, were not considered } \\
\text { a significant factor impairing patients' HRQoL. } \\
\text { Young male patients were more worried by risk of losing } \\
\text { of their jobs, while an impairment of sexual life due to } \\
\text { AS was more important to male than to female patients. }\end{array}$ \\
\hline
\end{tabular}

(Continued) 
Table 3 (Continued)

\begin{tabular}{lll}
\hline & Objective & $\begin{array}{l}\text { Demographic and clinical } \\
\text { characteristics }\end{array}$ \\
\hline Ariza-Ariza et $\mathrm{al}^{3 !}$ & To determine physical & AS ( $\mathrm{n}=92,25 \%$ female, mean age \\
(Spain) & function and HRQoL of & 40.7 [SD 9.I] years, disease duration \\
& Spanish patients with AS & II [SD 7.8] years)
\end{tabular}

Main results

BASFI had a good correlation (Pearson $>0.6$ ) with

PCS ( $\left.r=0.75, R^{2}=0.56 ; P<0.000 I\right)$, patient and physician

global assessment, pain measurements, BASDAl, and most HRQoL scores.

Physician global assessment $(P=0.043)$, patient paint assessment $(P=0.036)$, and BASFI score $(P=0.002)$ were independently associated with the SF36.

Only BASFI score showed an independent association with the EQ5D health profile $(P=0.002)$.

\begin{tabular}{lll}
\hline de las Peñas & To assess correlations & AS ( $\mathrm{n}=42,20 \%$ female, mean age \\
et a $\left.\right|^{32}$ (Spain) & among mobility, function, & 46 [SD 9] years, disease duration \\
& and HRQoL in subjects & I5 [SD 3] years) \\
& with AS
\end{tabular}

All domains of HRQoL except mental health were negatively correlated with BASFI score $(r=-0.35$ to $-0.75, P<0.05$ ).

Physical function, bodily pain, general health, vitality, and social role were negatively correlated with BASDAI score $(r=-0.35$ to $-0.63, P<0.05)$.

Few mobility measures of BASMI showed a positive correlation with SF36 domains: lumbar flexion (modified Schober) correlated with physical function $(r=0.36, P=0.03)$, and maximal intermalleolar distance correlated with physical function $(r=0.36, P=0.034)$ and social role $\left(r_{s}=0.33, P=0.04\right)$.

\begin{tabular}{lll}
\hline Ariza-Ariza et a ${ }^{33}$ & To identify variables & AS ( $n=70,24.7 \%$ female, mean age \\
(Spain) & associated with utility of & 43.7 [SD 9.1] years, disease duration \\
& health states in patients & I0.8 [SD 8.I] years) \\
& with AS
\end{tabular}

In the univariate analysis, patient global assessment $(r=-0.66, P<0.000 \mathrm{I})$, BASDAI $(r=-0.68, P<0.000 \mathrm{I})$, and BASFI $(r=-0.75, P<0.000 \mathrm{I})$ had good correlations with EQ5D values.

In the multivariate analysis, BASFI $(\beta=-0.0679, P=0)$ and BASDAI $(\beta=-0.044 \mathrm{I}, P=0.004) \mathrm{kept}$ an independent association with utility.

\begin{tabular}{ll}
\hline O’Dwyer et $\mathrm{a}^{34}$ & To assess health-related \\
(Ireland) & physical fitness of adults \\
& with AS, compare this to \\
& the general population, and \\
& examine the relationship \\
& between physical fitness and \\
& condition-specific outcomes
\end{tabular}

AS ( $n=39,18 \%$ female, mean age 40 [SD 9] years, disease duration $6[$ SD 10] years)
Compared to age- and sex-matched population controls, AS patients showed significantly lower cardiorespiratory fitness, flexibility, muscular strength and endurance, and increased body fat.

Physical fitness was associated with physical function (BASFI). Flexibility (BASMI) had the largest contribution of any individual physical fitness component, and accounted for $35.9 \%$ of the total variance in BASFI score $(\beta=-0.599, P=0.038)$.

Aerobic capacity was associated with HRQoL, accounting for $11.2 \%$ of the variance $(\beta=-0.334$, $P<0.00$ I).

Disease activity was not associated with any physical fitness component.

Physical domains of PsAID - pain $(0.72, P<0.000 \mathrm{I})$, discomfort $(0.73, P<0.000 \mathrm{I})$, work and/or leisure activities $(0.70, P<0.000 \mathrm{I})$, and functional capacity $(0.68, P<0.000 \mathrm{I})$ - had stronger correlation with patients' assessment (PGA) than other PROs or physician-based assessments, such as HAD (0.59, $P<0.000 \mathrm{I})$ and SF36 PCS $(-0.56, P<0.000 \mathrm{I})$.

A good correlation was established between PGA and psychological and social impact of PsAID: coping ( 0.77 , $P<0.000 \mathrm{I})$, anxiety $(0.68, P<0.000 \mathrm{I})$, fatigue $(0.66$, $P<0.000 \mathrm{I})$, depression $(0.65, P<0.000 \mathrm{I})$, and social participation $(0.58, P<0.000 \mathrm{I})$. A moderate or low correlation was found between PGA and impact related to skin $(0.34-0.47, P<0.000$ I). Joint counts were poorly correlated with PGA $(0.24-0.52, P<0.000 I)$. 
Table 3 (Continued)

\begin{tabular}{|c|c|c|c|}
\hline & Objective & $\begin{array}{l}\text { Demographic and clinical } \\
\text { characteristics }\end{array}$ & Main results \\
\hline & & & $\begin{array}{l}\text { PGA assessment was explained by coping }(\beta=0.287) \text {, } \\
\text { pain }(\beta=0.540) \text {, work and/or leisure activities }(\beta=0.14 \mathrm{I}) \text {, } \\
\text { and anxiety }(\beta=0.109) \text {. }\end{array}$ \\
\hline $\begin{array}{l}\text { Puyraimond- } \\
\text { Zemmour et } \mathrm{al}^{36} \\
\text { (multicenter) }\end{array}$ & $\begin{array}{l}\text { To explore the link between } \\
\text { PASS and patient-perceived } \\
\text { impact in RA and PsA }\end{array}$ & 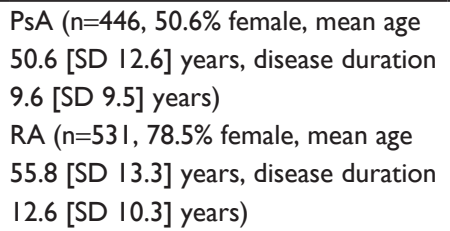 & $\begin{array}{l}\text { Multivariate analyses of the five domains of } \\
\text { PsAID - pain, functional capacity, fatigue, sleep } \\
\text { disturbance, and coping - indicated that in PsA patients, } \\
\text { pain (OR } 0.63,95 \% \mathrm{Cl} 0.52-0.75 \text { ) and coping (OR } \\
0.63,95 \% \mathrm{Cl} 052-0.75 \text { ) were associated in PASS after } \\
\text { adjustment on DAS28 (OR } 0.83,95 \% \mathrm{Cl} 0.7 \mathrm{I}-0.97) \text {. }\end{array}$ \\
\hline $\begin{array}{l}\text { Brodszky et al }{ }^{37} \\
\text { (Hungary) }\end{array}$ & $\begin{array}{l}\text { To compare PsAQoL, HAQ, } \\
\text { and EQ5D in terms of ability } \\
\text { to assess disease severity } \\
\text { in PsA }\end{array}$ & $\begin{array}{l}\text { PsA ( } n=183,57 \% \text { female, mean age } \\
51 . I \text { [SD 12.9] years, disease duration } \\
9.2 \text { [SD 9.2] years) }\end{array}$ & $\begin{array}{l}\text { EQ5D and PsAQoL scores were strongly correlated } \\
\text { with clinical variables, such as HAD }(-0.7 I \text { to } 0.64 \text {, } \\
P<0.05) \text {, BASDAI ( }-0.69 \text { to } 0.62, P<0.05) \text {, PGA }(-0.63 \\
\text { to } 0.52, P<0.05) \text {, and patient pain VAS ( }-0.68 \text { to } 0.54 \text {, } \\
P<0.05) \text {. } \\
\text { Disease duration ( }-0.14 \text { to } 0.15, P<0.05 \text { ) and psoriasis } \\
\text { ( }-0.13 \text { to } 0.12 \text {, not significant) correlated weakly with } \\
\text { HRQoL instruments. }\end{array}$ \\
\hline
\end{tabular}

Abbreviations: axSpA, axial spondyloarthritis; AS, ankylosing spondylitis; BAs, biological agents; BASDAI, Bath Ankylosing Spondylitis Disease Activity Index; BASFI, BAS Functional Index; BASMI, BAS Metrology Index; DAS, disease-activity score; EQ, EuroQol; ESR, erythrocyte-sedimentation rate; HAQ; Health Assessment Questionnaire; HRQoL, health-related quality of life; MCS, mental component summary; nr, nonradiographic; PASS, patient-acceptable symptom state; PCS, physical component summary; PGA, patient global assessment; PHQ 9, Patient Health Questionnaire; PsA, psoriatic arthritis; PsAID, Psoriatic Arthritis Impact of Disease; SF, Short Form; VAS, visual analog scale.

In addition, around $50 \%$ of patients indicated that the need for assistance in activities of daily living (ADL) and impairment in family life potentially influenced their HRQoL. Young male patients were more concerned by the risk of losing their jobs than older ones, while impairment of sexual life due to the disease was more important to males than to females. Management of the disease (treatment or frequent hospitalization) was not considered a significant factor impairing their HRQoL.

\section{Patient-reported measures and HRQoL in AS patients} Mobility and physical function are the most important end points for AS patients, and several instruments have been developed to evaluate disease activity from patient perspectives (BAS Disease Activity Index [BASDAI]) and physical functioning (BASFI and BAS Metrology Index). A correlation between physical function (BASFI) and HRQoL in AS patients was established by Ariza-Ariza et al, ${ }^{31}$ showing that BASFI score presented an independent association with HRQoL. This association was confirmed by de las Peñas et al. ${ }^{32}$ These authors observed that function (BASFI) and disease activity (BASDAI) were correlated with HRQoL (physical function, pain, and vitality domains). In the same vein, Ariza-Ariza et $\mathrm{al}^{33}$ found that physical function (BASFI) and disease activity (BASDAI) were the main determinants of health-state utility values in AS patients. Finally, a recent study published by O'Dwyer et $\mathrm{al}^{34}$ confirmed that adults with AS show a significant reduction in physical fitness compared to age- and sex-matched healthy controls. The AS group demonstrated significantly lower cardiorespiratory fitness, flexibility, muscular strength, and increased body fat compared to controls. All components of physical fitness were associated with physical function (BASFI), while only aerobic capacity was associated with HRQoL (ASQoL).

\section{HRQoL in PsA patients}

\section{Patient-reported measures and HRQoL in} PsA patients

Tälli et $\mathrm{al}^{35}$ showed that patient global assessment (PGA) in PsA was determined mainly by physical but also physiological aspects of the disease. In particular, coping, pain, work, leisure activities, and anxiety were identified as the main explanatory factors for PGA scores. Skin lesions seemed to have a lower impact on PGA than joint involvement, which had a larger effect on PsA patients' HRQoL. Similarly, Puyraimond-Zemmour et $\mathrm{al}^{36}$ established an association between pain and coping with patient-acceptable symptom state, showing that less pain and better coping were correlated with better level of acceptability of disease status.

\section{Disease severity and HRQoL in PsA patients}

Brodsky et $\mathrm{al}^{37}$ found strong correlations between both generic (EuroQol 5D) and specific HRQoL (PsAQoL) instruments 
and disease severity assessed by Health Assessment Questionnaire (HAQ) disability score, patient-pain visual analog scale, PGA, and BASDAI. However, disease duration and psoriasis correlated weakly with these HRQoL instruments.

\section{Compliance and persistence in SpA patients}

According to the definition of adherence/compliance (extent to which patient acts in accordance the prescribed interval and dose of dosing regimen) and persistence (duration of time from initiation to discontinuation of therapy), ${ }^{38}$ five studies evaluated persistence to BA therapy in SpA patients, one assessed compliance with BA treatment, while the remaining publication was a systematic review (Table 4).

The systematic review ${ }^{39}$ reported great variability in the operational definition and measurement of adherence/ compliance among studies. Most studies focused on persistence, measured by survival time, retention, or continuation rates, while fewer publications assessed adherence based on proportion of days covered or medication-possession ratio. The results suggested better compliance with biological therapy in SpA compared to RA. Age, female sex, comorbidity,

Table 4 Characteristics of adherence/persistence-related observational studies reviewed

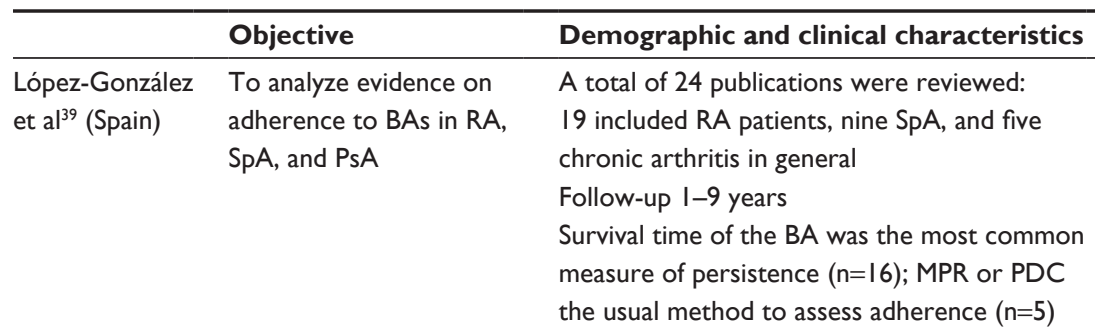

\begin{tabular}{lll}
\hline Lyu et al $^{40}$ & To evaluate treatment & RA ( $\mathrm{n}=576,75 \%$ female, mean age 56.9 years, \\
(Germany) & persistence among RA, & SD I3.I years) \\
& AS, and PsA patients & AS ( $n=108,29.6 \%$ female, mean age 42 years, \\
& initiating subcutaneous & SD II.5 years) \\
& BAs in Germany & PsA ( $n=197,50.3 \%$ female, mean age \\
& & 49.4 years, SD I0.6 years) \\
\hline Saad et al ${ }^{41}$ & To assess persistence & PsA ( $n=566,53 \%$ female, mean age 45.7 years, \\
$($ UK) & with first-course and & SD II.I years), disease duration I2.4 years, \\
& second-course treatment & SD 8.7 years \\
& with BAs in PsA patients &
\end{tabular}

\section{Main results}

Adherence to BAs was superior in SpA over RA.

Several factors were identified as adherence predictors. Women were less adherent than men.

A poor clinical condition at baseline was associated with lower persistence; however, high baseline CRP improved overall persistence. Methotrexate and other DMARDs increased adherence, but the number of previous DMARDs was associated with premature treatment discontinuation.

Persistence rates over 12 months were $51.9 \%$, 48. $1 \%$, and $57.9 \%$ for RA, AS, and PsA patients, respectively.

In AS and PsA, there was no significant difference in the time to discontinuation for naïve compared to experienced patients.

At 12-month follow-up, 75.5\% remained on their
first BA, while $9.5 \%$ discontinued treatment due to inefficacy and $10 \%$ due to AEs.

Being female (HR I.5, 95\% Cl I.0-I.7) and having baseline comorbidity (HR I.5, 95\% IC I.I-2.0) were associated with significantly higher drugdiscontinuation rates.

Persistence with the second course of therapy was lower than with the first course.

\begin{tabular}{lll}
\hline Kristensen & To examine clinical & Isolated AS ( $\mathrm{n}=122,25 \%$ female, mean age \\
et $\mathrm{al}^{42}$ (Sweden) & characteristics as possible & 42 years, SD I2 years), disease duration \\
& $\begin{array}{l}\text { predictors of long-term } \\
\text { treatment continuation }\end{array}$ & I5 years, SD I2 years \\
& AS peripheral arthritis ( $\mathrm{n}=12$ I, I0\% female, \\
& with BAs in naïve AS & mean age 44 years, SD I2 years), disease \\
& patients & duration I6 years, SD I2 years
\end{tabular}
Drug-survival rates at 12 and 24 months were $86 \%$ and $78 \%$ for patients with peripheral arthritis and $74 \%$ and $68 \%$ for patients with isolated SA $(P=0.05)$.

In both groups, at 24 months II\% of withdrawals were due to AEs and $13 \%$ due to inefficacy. After 12 and 24 months, $93 \%$ and $85 \%$ of the patients with improvement in VAS global remained on treatment, while only $79 \%$ and $68 \%$ continued the treatment in the less favorable VAS global response $(P<0.0 \mathrm{I})$, respectively. Male sex (discontinuation HR $0.36,95 \% \mathrm{Cl}$ $0.19-0.68)$ and presence of peripheral arthritis (HR 0.49, 95\% Cl 0.27-0.88) were found to be statically significant predictors for continuation of therapy. This impact seemed to be mainly related to a lower risk of ceasing treatment due to inefficacy. 
Table 4 (Continued)

\begin{tabular}{|c|c|c|c|}
\hline & Objective & Demographic and clinical characteristics & Main results \\
\hline $\begin{array}{l}\text { Wallman et } \mathrm{al}^{29} \\
\text { (Sweden) }\end{array}$ & $\begin{array}{l}\text { To compare clinical } \\
\text { development, HRQoL } \\
\text { and treatment adherence } \\
\text { between nr-axSpA and } \\
\text { AS patients during } 3 \text { years } \\
\text { of BAs in clinical practice }\end{array}$ & $\begin{array}{l}n r-a x S p A(n=86,38 \% \text { female, mean age } \\
38 \text { years, SD } 13 \text { years), disease duration } \\
9 \text { years, SD } 9 \text { years } \\
\text { AS ( } n=238,24 \% \text { female, mean age } 43 \text { years, } \\
\text { SD } 12 \text { years), disease duration } 16 \text { years, } \\
\text { SD } 12 \text { years }\end{array}$ & $\begin{array}{l}\text { After } 3 \text { years of follow-up, the proportion of } \\
\text { patients with nr-axSpA and AS remaining on BA } \\
\text { therapy was } 70 \% \text { and } 77 \% \text {, respectively. } \\
\text { Male sex and higher brazilein CRP levels were } \\
\text { significantly associated with better treatment } \\
\text { persistence. }\end{array}$ \\
\hline $\begin{array}{l}\text { Favalli et } \mathrm{al}^{43} \\
\text { (Italy) }\end{array}$ & $\begin{array}{l}\text { To evaluate the } 8 \text {-year } \\
\text { survival of first-BA } \\
\text { patients with axSpA } \\
\text { or PsA and identify } \\
\text { predictive factors for } \\
\text { withdrawal }\end{array}$ & $\begin{array}{l}\text { PsA ( } n=298,48.3 \% \text { female, mean age } \\
47.8 \text { years, SD } 12.1 \text { years), disease duration } \\
8.7 \text { years, SD } 7.7 \text { years } \\
\text { axSpA ( } n=316,30 \% \text { female, mean age } \\
42.8 \text { years, SD } 12.1 \text { years), disease duration } \\
7.2 \text { years, SD } 7.9 \text { years }\end{array}$ & $\begin{array}{l}\text { The cumulative } 8 \text {-year retention rate was } 5 \mathrm{I} .9 \% \text { in } \\
\text { PsA patients and } 57.2 \% \text { in axSpA patients. } \\
43.1 \% \text { of patients with PsA and } 42.1 \% \text { with axSpA } \\
\text { stopped the first-line BA. } 22.4 \% \text { of patients } \\
\text { with PsA and I5.8\% with axSpA reported that } \\
\text { discontinuation was due to inefficacy, while I5\% } \\
\text { and } 41.2 \% \text { of patients, respectively, indicated that } \\
\text { they stopped the treatment due to AEs. } \\
\text { Male sex (HR } 0.595,95 \% \text { CI } 0.405-0.875 ; \\
\text { P=0.008) and concomitant methotrexate use were } \\
\text { associated with a lower overall risk of withdrawal } \\
\text { in PsA, but not in axSpA patients. High baseline } \\
\text { BASDAI was a predictor of drug persistence in } \\
\text { axSpA (HR I.0I6, } 95 \% \mathrm{CI} \text { I.002-I.030; } P=0.028 \text { ). }\end{array}$ \\
\hline $\begin{array}{l}\text { Hromadkova } \\
\text { et } \mathrm{al}^{26} \text { (Czech } \\
\text { Republic) }\end{array}$ & $\begin{array}{l}\text { To elucidate the } \\
\text { relationship between drug } \\
\text { compliance and HRQoL } \\
\text { in patients with different } \\
\text { rheumatic disorders }\end{array}$ & $\begin{array}{l}\mathrm{SpA}(\mathrm{n}=4 \mathrm{I}, 68.1 \% \text { female, mean age } 50(22-79) \\
\text { years), disease duration } 3.8(0.7-8.3) \text { years } \\
\text { RA }(n=I 78,78.7 \% \text { female, mean age } 59 \\
(26-82) \text { years), disease duration } 7.4 \\
(0.5-19.9) \text { years } \\
\text { SSc }(n=4 I, 75.6 \% \text { female, mean age } 58(26-80) \\
\text { years), disease duration } 6.8(0.5-23.9) \text { years } \\
\text { JIA }(n=23,73.9 \% \text { female, mean age } 28(18-5 I) \\
\text { years), disease duration } 6.8(0.6-20.9) \text { years }\end{array}$ & $\begin{array}{l}\text { Mean CQR score }(0 \text { nonadherence to } 100 \\
\text { complete adherence) in SpA patients was } 77 . \text { I } \\
(42.1-97.9) \text {. } \\
38.3 \% \text { of patients with SpA were considered } \\
\text { compliant (CQR }<80) \text {. } \\
\text { Patients with JIA were the least adherent } \\
\text { (CQR 66), while patients with RA presented } \\
\text { higher rates of adherence (CQR } 82.5) \text {. }\end{array}$ \\
\hline
\end{tabular}

Abbreviations: axSpA, axial spondyloarthritis; AS, ankylosing spondylitis; BAs, biological agents; CQR, Compliance Questionnaire Rheumatology; HRQoL, health-related quality of life; JIA, juvenile idiopathic arthritis; MPR, medication-possession ratio; nr-axSpA, nonradiographic axial spondyloarthritis; PDC, proportion of days covered; PsA, psoriatic arthritis; SSc, systemic sclerosis.

poor clinical condition, and number of previous BAs were identified as explanatory factors for patient compliance.

Results of persistence in SpA patients were heterogeneous among the studies reviewed. Lyu et $\mathrm{a}^{40}$ observed that among AS and PsA patients who were initiating biological treatment, persistence at 12 months was relatively low (48\%-58\%). Nonetheless, Saad et al ${ }^{41}$ reported a higher survival rate on their index BA (75.5\%) for patients with PsA after 12 months of follow-up. In line with these results, Kristensen et a ${ }^{42}$ showed drug-survival rates at 12 and 24 months of $86 \%$ and $78 \%$ for peripheral arthritis patients and $74 \%$ and $68 \%$ for patients with isolated AS starting biological therapy. Likewise, Wallman et $\mathrm{al}^{29}$ showed a high proportion of patients with nr-axSpA (70\%) and AS (77\%) remaining on BA therapy after three years follow up. For long-term persistence, Favalli et al ${ }^{43}$ reported cumulative 8-year retention of $57.2 \%$ for axSpA and $51.9 \%$ for PsA. Finally, related to compliance, Hromadkove et $\mathrm{al}^{26}$ reported that only $38.3 \%$ of patients with AS were compliant with BA treatment, as indicated by Compliance Questionnaire Rheumatology score $(\geq 80)$.

\section{Satisfaction with decision making}

Renzi et $\mathrm{al}^{44}$ examined PsA patients' preferences about their role in the decision-making process, as well as their satisfaction with both their care and their knowledge about PsA therapies (Table 5). Overall, the majority of PsA patients (72.7\%) wanted to be involved in decision making, although $40.6 \%$ preferred that their doctors make the final decision after considering their opinion; $65.5 \%$ of PsA patients reported being completely or fairly satisfied with their care and information. Multivariate analysis showed that information on both treatment side effects and treatment options was significantly associated with overall satisfaction, confirming that improving patient-doctor communication may improve patients' satisfaction with their care.

\section{Patient preferences for SpA treatments}

Two publications examined patient preferences for treatment characteristics (Table 5). Nolla et $\mathrm{al}^{45}$ assessed the relative importance given by patients with rheumatic diseases (RA, AS, and PsA) and rheumatologists to attributes of BAs. 
Table 5 Characteristics of studies of satisfaction and preferences for treatment that were reviewed

\begin{tabular}{|c|c|c|c|}
\hline & Objective & $\begin{array}{l}\text { Demographic and clinical } \\
\text { characteristics }\end{array}$ & Main results \\
\hline $\begin{array}{l}\text { Renzi et al }{ }^{44} \\
\text { (Italy) }\end{array}$ & $\begin{array}{l}\text { To examine } \\
\text { attitudes toward } \\
\text { and satisfaction with } \\
\text { decision making of } \\
\text { patients with PsA } \\
\text { compared with } \\
\text { patients who had } \\
\text { cutaneous psoriasis }\end{array}$ & $\begin{array}{l}\text { PsA }(n=33,51 \% \text { female, } 61.5 \% \\
\text { aged } \leq 50 \text { years, disease duration } \\
76.9 \%<12 \text { years }) \\
\text { Pso }(n=207,29.5 \% \text { female, } 64.7 \% \\
\text { aged } \leq 50 \text { years, disease duration } \\
54.4 \%<12 \text { years })\end{array}$ & 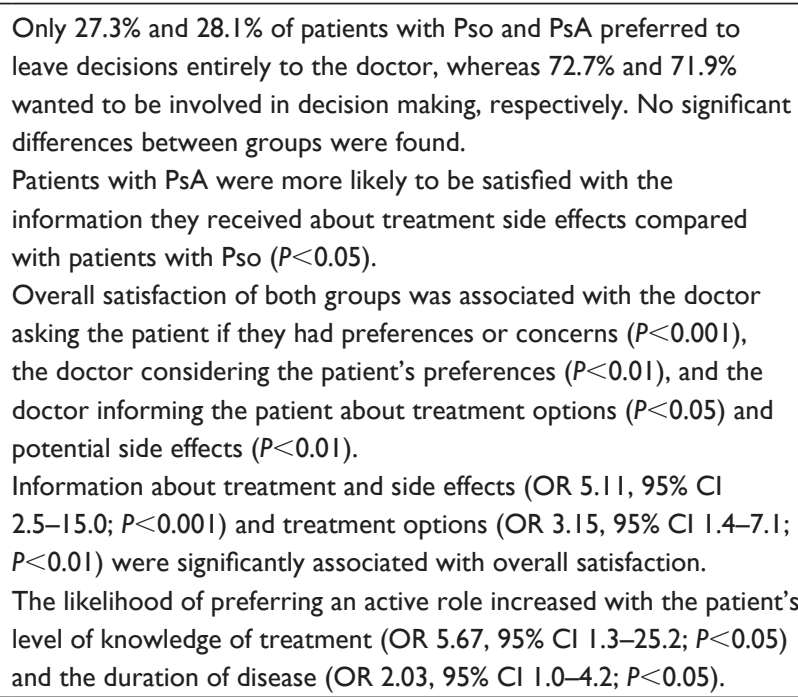 \\
\hline $\begin{array}{l}\text { Nolla et al }{ }^{45} \\
\text { (Spain) }\end{array}$ & $\begin{array}{l}\text { To define } \\
\text { importance of } \\
\text { values assigned to } \\
\text { attributes of BAs by } \\
\text { Spanish patients with } \\
\text { rheumatic diseases } \\
\text { (RA, AS, and PsA) } \\
\text { and rheumatologists }\end{array}$ & $\begin{array}{l}\text { AS ( } \mathrm{n}=\mid 58,28.2 \% \text { female, mean } \\
\text { age } 46.3 \text { [SD II.4] years, disease } \\
\text { duration I3.I [SD 9.2] years) } \\
\text { PsA ( } \mathrm{n}=\mid 65,44.2 \% \text { female, mean } \\
\text { age } 49.5 \text { [SD II.4] years, disease } \\
\text { duration I2.6 [SD 8.2] years) } \\
\text { RA ( } \mathrm{n}=165,73.8 \% \text { female, mean } \\
\text { age } 55.9 \text { [SD II.5] years, disease } \\
\text { duration I3 [SD 7.8] years) } \\
\text { Treatment: I00\% of study } \\
\text { participants were currently being } \\
\text { treated with BAs, 34\% had received } \\
\text { previous treatment with BAs }\end{array}$ & $\begin{array}{l}\text { Independently of the diagnosis, patients placed more importance on } \\
\text { pain relief and improvement in functional capacity (RI AS } 37.8 \% \text {, RI } \\
\text { PsA } 4 \text { I.6\%, RI AR } 37.5 \% \text { ), followed by the risk of AEs (RI AS 39\%, RI } \\
\text { PsA\%, RI AR\%), administration methods (RI AS } 25.7 \% \text {, RI PsA } 24.6 \% \text {, } \\
\text { RI AR } 24.3 \% \text { ), and duration of effect (time until perceiving the need } \\
\text { for a new dose) (RI AS I7.I\%, RI PsA I5\%, RI AR I7.2\%). }\end{array}$ \\
\hline $\begin{array}{l}\text { Rothery } \\
\text { et al }{ }^{46} \text { (UK) }\end{array}$ & $\begin{array}{l}\text { To assess patients' } \\
\text { preferences for } \\
\text { treatment-related } \\
\text { benefits and risk of } \\
\text { disease relapse in } \\
\text { the management } \\
\text { of patients in low } \\
\text { disease states of PsA }\end{array}$ & $\begin{array}{l}\text { PsA }(\mathrm{n}=136,46.6 \% \text { female, } 56.3 \% \\
\text { aged } \geq 55 \text { years, } 57 \%<9 \text { years' } \\
\text { disease duration) } \\
\text { Treatment } 31.2 \% \text { methotrexate } \\
\text { alone, } 15.4 \% \text { other cDMARDs } \\
\text { alone, } 12.2 \% \text { BAs alone, } 27.5 \% \\
\text { methotrexate combined with } \\
\text { cDMARDs or BAs, } 3.2 \% \text { other } \\
\text { cDMARDs combined with } \\
\text { BA, } 10.5 \% \text { no medication }\end{array}$ & $\begin{array}{l}\text { The most important benefit attribute was the elimination of severe } \\
\text { side effects of sickness and nausea (weights } 1.8668 \text { and } 0.7996, \\
\text { respectively). } \\
\text { Patients were willing to accept a very large increase in risk of } \\
\text { relapse in exchange for improvements in levels of sickness/nausea } \\
\text { ( } 76.1 \% \text { severe to some sickness/nausea, } 32.6 \% \text { some to no sickness/ } \\
\text { nausea) and health status ( } 30.1 \% \text { health state } 3 \text { [no problems with } \\
\text { mobility or self-care, some problems with performing usual activities, } \\
\text { moderate pain or discomfort, and moderate anxiety or depression] } \\
\text { to } 2 \text { [no problems with mobility, self-care, anxiety, or depression, } \\
\text { some problems with performing usual activities, moderate pain or } \\
\text { discomfort], } 38.6 \% \text { health state I [no problems with mobility or self- } \\
\text { care, usual activities, pain or discomfort, anxiety or depression] to 3). }\end{array}$ \\
\hline
\end{tabular}

Abbreviations: AE, adverse event; AS, ankylosing spondylitis; BAs, biological agents; cDMARDs, conventional disease-modifying antirheumatic drugs; HRQoL, health-related quality of life; PsA, psoriatic arthritis; Pso, psoriasis; RI, relative importance; SpA, spondyloarthritis.

For these patients, although efficacy (pain relief and improvement in functional capacity) and safety (risk of adverse events) were key aspects, both the frequency (time until perceiving the need for a new dose) and method of administration played an important role as attributes of BAs. Rothery et a ${ }^{46}$ observed that PsA patients conferred the greatest importance to eliminating severe side effects of sickness/nausea and the least importance to a change in risk of relapse. Patients were willing to accept a large increase in the risk of relapse in order to reduce the side effects of sickness/nausea.

\section{Discussion}

This review reports current knowledge on PROs in SpA patients in the EU. To date, the evidence indicates that similar to other rheumatic conditions, ${ }^{47} \mathrm{SpA}$ patients report poorer 
HRQoL compared to the general population. For AS patients, physical domains were more impaired than emotional wellbeing, whereas for PsA patients both physical and psychological factors were strongly affected by the disease. Indeed, prevalence of depressive symptoms was higher in PsA than in AS and particularly high in patients with polyarthritis. In PsA, anxiety symptoms and concern about somatic symptoms were independently correlated with HRQoL, while in AS patients only impairment of cognitive function was found to be associated with HRQoL deterioration.

Work disability is a major problem for SpA patients. Indeed, these diseases tend to occur in the working-age population, and studies have suggested that the ability to work and to perform ADL positively influence patients' perceptions of their physical performance. In a cross-sectional study conducted in the US, limitations in ADL were significantly associated with lower PCS scores in patients with AS whereas for PsA patients ADL limitations were associated with both lower PCS and MCS scores, which supports results from EU reports in this review.

The PCS in AS patients is important. In these patients, physical restrictions in joint mobility, particularly of the spine, ${ }^{48,49}$ in addition to reductions in aerobic capacity ${ }^{50,51}$ and loss of skeletal muscle, ${ }^{52,53}$ are frequent. We found that physical function measured by the BASFI was highly correlated with HRQoL, indicating that functional impairment associated with AS can cause a significant impact on patients' HRQoL, with important limitations on their daily activities. Conversely, PsA is a heterogeneous disease that is greatly influenced by psychological and social aspects of the disease. The most affected aspects of HRQoL in PsA patients were coping with a chronic disease, limitations on work and/or leisure time, and anxiety or depression. Interestingly, joint symptoms had a greater effect on PsA patients' lives than skin symptoms.

Overall, SpA treatment has changed dramatically with the development of BAs. ${ }^{11-13}$ Substantial improvements in the signs and symptoms of PsA patients have been reported for these agents, although all BAs are similar in terms of efficacy and safety. ${ }^{54}$ The current evidence suggests that routine clinical use of BAs contributes greatly to the improvement of HRQoL in SpA patients. Significantly, the greatest improvements were found in the PCS, with smaller but still significant improvements in the MCS.

However, the potential clinical benefits demonstrated by BAs in clinical trials may be reduced by poor adherence and early discontinuation of treatment in clinical practice, thereby increasing medical costs and resulting in the need for more aggressive treatments. ${ }^{55-57}$ Results on compliance with biological treatment of SpA patients were heterogeneous in real-life situations; nonetheless, all rates of persistence at 12 months were $>50 \%$ of the population, with no significant differences between PsA and AS patients and irrespective of the individual BA administered. A recent retrospective cohort study ${ }^{58}$ conducted in 53,477 BA-naïve patients with rheumatic conditions in the US reported that the majority of patients remained persistent in the first year of BA therapy; however, they observed lower adherence ratios when 12-month medication-possession ratios were measured. Overall, in line with our results, patient characteristics, such as male sex, high disease activity, or peripheral arthritis, and treatment characteristics, such as concomitant methotrexate use, positively influence treatment persistence. Interestingly, higher HRQoL and a lower rate of functional disability were associated with lower compliance with treatment. According to Calip et al, ${ }^{58}$ young adults were less likely to be treatmentcompliant, resulting in more comorbidities, hospitalizations, or visits to the emergency department.

In rheumatic diseases, assessing and including patient preferences in the decision-making process have been found to contribute to increased medication adherence, improved treatment outcomes, reduced health care costs, and enhanced patient satisfaction. ${ }^{59-61}$ The available evidence suggests that European SpA patients attach great importance to outcomes (pain relief and improvement of functional capacity, low risk of adverse events); however, process attributes, such as selfadministration at home or longer time between doses, were also considered important attributes for BAs. Preferences varied depending on the PsA-disease states: low-diseasestate patients were more concerned about the side effects of sickness/nausea than about the risk of relapse.

Results on PsA patients confirm that most patients want to be involved in decision making about their treatment. Satisfaction was associated with doctors providing treatment information and actively involving patients in decision making. In line with these results, Nota et $\mathrm{a}^{62}$ reported that most patients with rheumatic disease preferred to be involved in decisions about their medication and especially preferred more participation in decision making regarding their first treatment, which most commonly occurs in newly diagnosed patients.

\section{Limitations}

Possible limitations of this review include the heterogeneity of the articles retrieved in terms of patients, treatments, or methodology. Regarding the design, all studies assessing HRQoL in SpA were cross-sectional, and it is important to take into account that cross-sectional design might limit 
comparisons among SpA patients and with other diseases and does not allow the drawing of final conclusions about the factors associated with HRQoL and their cause-effect relationship. On the other hand, there may be relevant publications in languages other than English and Spanish or that are indexed in different databases than those searched that we have not identified in this review.

\section{Conclusion}

SpA has a negative impact on patients' HRQoL. The physical aspects of HRQoL, especially functioning limitations and pain, are severely affected in both AS and PsA patients. In PsA patients, the impact of disease on emotional well-being is considerable. In both disease, BA therapy is associated with improvements in both physical and emotional status. However, these potential improvements may be reduced by poor adherence. Even though there are inconsistent findings, persistence rates in SpA patients are $>50 \%$, irrespective of the individual BA administered. Finally, results on preferences showed that most SpA patients preferred to be involved in decisions regarding their treatment, and although efficacy and safety are both considered essential, frequency and methods of administration also play a role as preference attributes for BA. These findings suggest that implementing management programs for $\mathrm{SpA}$ patients focused on the physical, emotional, and social consequences of the disease, in addition to assessing and including patient's preferences in the treatment decision-making process, could be crucial in improving patients' HRQoL and ensuring their satisfaction and compliance with treatment.

\section{Acknowledgment}

The abstract was presented at ISPOR Congress 2016. The full details of the reference are: Blanch $\mathrm{C}$, Comellas $\mathrm{M}$, de Paz HD, Lizan L. Patient reported outcomes in spondyloarthritis patients in Europe: a systematic review of the literature. Value Health; 19(7):A543.

\section{Disclosure}

This study was funded by Novartis Farmacéutica SA. CB works for Novartis Farmacéutica SA. MC and LL work for an independent research entity that received remuneration for development of the original research and writing this manuscript. The remaining authors report no conflicts of interest in this work.

\section{References}

1. National Institute for Health and Care Excellence. Spondyloarthritis in Over 16s: Diagnosis and Management. London: NICE; 2017.
2. Raychaudhuri SP, Raychaudhuri SK. Mechanistic rationales for targeting interleukin-17A in spondyloarthritis. Arthritis Res Ther. 2017;19(1):51.

3. Wendling D. Treating to target in axial spondyloarthritis: defining the target and the arrow. Expert Rev Clin Immunol. 2015;11(6):691-693.

4. Stolwijk C, Boonen A, van Tubergen A, Reveille JD. Epidemiology of spondyloarthritis. Rheum Dis Clin North Am. 2012;38(3):441-476.

5. Gladman DD, Antoni C, Mease P, Clegg DO, Nash P. Psoriatic arthritis: epidemiology, clinical features, course, and outcome. Ann Rheum Dis. 2005;64(Suppl 2):ii14-ii17.

6. Liu JT, Yeh HM, Liu SY, Chen KT. Psoriatic arthritis: epidemiology, diagnosis, and treatment. World J Orthop. 2014;5(4):537-543.

7. Singh JA, Strand V. Spondyloarthritis is associated with poor function and physical health-related quality of life. J Rheumatol. 2009;36(5): 1012-1020.

8. Loza E, Jover JA, Rodriguez L, Carmona L. Multimorbidity: prevalence, effect on quality of life and daily functioning, and variation of this effect when one condition is a rheumatic disease. Semin Arthritis Rheum. 2009;38(4):312-319.

9. al Maini M, Adelowo F, al Saleh J, et al. The global challenges and opportunities in the practice of rheumatology: white paper by the World Forum on Rheumatic and Musculoskeletal Diseases. Clin Rheumatol. 2015;34(5):819-829.

10. el Maghraoui A. Extra-articular manifestations of ankylosing spondylitis: prevalence, characteristics and therapeutic implications. Eur $J$ Intern Med. 2011;22(6):554-560.

11. Smolen JS, Landewé R, Breedveld FC, et al. EULAR recommendations for the management of rheumatoid arthritis with synthetic and biological disease-modifying antirheumatic drugs: 2013 update. Ann Rheum Dis. 2014;73(3):492-509.

12. Braun J, van den Berg R, Baraliakos X, et al. 2010 Update of the ASAS/EULAR recommendations for the management of ankylosing spondylitis. Ann Rheum Dis. 2011;70(6):896-904.

13. Gossec L, Smolen JS, Gaujoux-Viala C, et al. European League Against Rheumatism recommendations for the management of psoriatic arthritis with pharmacological therapies. Ann Rheum Dis. 2012;71(1):4-12.

14. Schoels M, Knevel R, Aletaha D, et al. Evidence for treating rheumatoid arthritis to target: results of a systematic literature search. Ann Rheum Dis. 2010;69(4):638-643.

15. Kavanaugh A, Cohen S, Cush JJ. The evolving use of tumor necrosis factor inhibitors in rheumatoid arthritis. $J$ Rheumatol. 2004;31(10): 1881-1884.

16. Hill J. Adherence with drug therapy in the rheumatic diseases - part one: a review of adherence rates. Musculoskeletal Care. 2005;3(2):61-73.

17. Barton JL. Patient preferences and satisfaction in the treatment of rheumatoid arthritis with biologic therapy. Patient Prefer Adherence. 2009;3:335-344.

18. Higgins JP, Green S. Cochrane Handbook for Systematic Reviews of Interventions. Version 5.1.0. London: Cochrane Collaboration; 2011.

19. Centre for Evidence-Based Medicine [homepage on the Internet] Available from: https://www.cebm.net. Accessed March 26, 2018.

20. Salaffi F, Carotti M, Gasparini S, Intorcia M, Grassi W. The healthrelated quality of life in rheumatoid arthritis, ankylosing spondylitis, and psoriatic arthritis: a comparison with a selected sample of healthy people. Health Qual Life Outcomes. 2009;7:25.

21. Jajić Z, Rajnpreht I, Kovačić N, et al. Which clinical variables have the most significant correlation with quality of life evaluated by SF-36 survey in Croatian cohort of patient with ankylosing spondylitis and psoriatic arthritis? Rheumatol Int. 2012;32(11):3471-3479.

22. Kotsis K, Voulgari PV, Tsifetaki N, et al. Anxiety and depressive symptoms and illness perceptions in psoriatic arthritis and associations with physical health-related quality of life. Arthritis Care Res (Hoboken). 2012; 64(10):1593-1601.

23. Hyphantis T, Kotsis K, Tsifetaki N, et al. The relationship between depressive symptoms, illness perceptions and quality of life in ankylosing spondylitis in comparison to rheumatoid arthritis. Clin Rheumatol. 2013; 32(5):635-644. 
24. Chorus AM, Miedema HS, Boonen A, van der Linden S. Quality of life and work in patients with rheumatoid arthritis and ankylosing spondylitis of working age. Ann Rheum Dis. 2003;62(12):1178-1184.

25. Kawalec P, Malinowski KP, Pilc A. Disease activity, quality of life and indirect costs of psoriatic arthritis in Poland. Rheumatol Int. 2016;36(9): $1223-1230$

26. Hromadkova L, Soukup T, Vlcek J. Quality of life and drug compliance: their interrelationship in rheumatic patients. J Eval Clin Pract. 2015;21(5): 919-924.

27. Saad AA, Ashcroft DM, Watson KD, et al. Improvements in quality of life and functional status in patients with psoriatic arthritis receiving anti-tumor necrosis factor therapies. Arthritis Care Res (Hoboken). 2010;62(3):345-353.

28. Sieper J, Holbrook T, Black CM, Wood R, Hu X, Kachroo S. Burden of illness associated with non-radiographic axial spondyloarthritis: a multiperspective European cross-sectional observational study. Clin Exp Rheumatol. 2016;34(6):975-983.

29. Wallman JK, Kapetanovic MC, Petersson IF, Geborek P, Kristensen LE. Comparison of non-radiographic axial spondyloarthritis and ankylosing spondylitis patients: baseline characteristics, treatment adherence, and development of clinical variables during three years of anti-TNF therapy in clinical practice. Arthritis Res Ther. 2015;17(1):378.

30. Kucharz EJ, Kotulska A, Kopeć-Mędrek M, Widuchowska M. Opinion of patients with ankylosing spondylitis on risk factors impairing their quality of life. Rheumatol Int. 2013;33(11):2899-2901.

31. Ariza-Ariza R, Hernández-Cruz B, Navarro-Sarabia F. Physical function and health-related quality of life of Spanish patients with ankylosing spondylitis. Arthritis Rheum. 2003;49(4):483-487.

32. de las Peñas CF, Blanco CA, Pérez AA, Page JC. Relationship among mobility, functionality and quality of life in subjects presenting with ankylosing spondylitis. Fisioterapia. 2006;28(3):143-151.

33. Ariza-Ariza R, Hernández-Cruz B, López-Antequera G, NavarroSarabia F. Variables related to utility in patients with ankylosing spondylitis. Clin Rheumatol. 2009;28(2):207-211.

34. O'Dwyer T, O'Shea F, Wilson F. Decreased health-related physical fitness in adults with ankylosing spondylitis: a cross-sectional controlled study. Physiotherapy. 2016;102(2):202-209.

35. Tälli S, Etcheto A, Fautrel B, et al. Patient global assessment in psoriatic arthritis: what does it mean? An analysis of 223 patients from the Psoriatic Arthritis Impact of Disease (PsAID) study. Joint Bone Spine. 2016;83(3):335-340.

36. Puyraimond-Zemmour D, Etcheto A, Fautrel B, et al. Associations between five important domains of health and the patient acceptable symptom state in rheumatoid arthritis and psoriatic arthritis: a cross-sectional study of 977 patients. Arthritis Care Res (Hoboken). 2017;69(10):1504-1509.

37. Brodszky V, Péntek M, Bálint P, et al. Comparison of the Psoriatic Arthritis Quality of Life (PsAQoL) questionnaire, the functional status (HAQ) and utility (EQ-5D) measures in psoriatic arthritis: results from a cross-sectional survey. Scand J Rheumatol. 2010;39(4):303-309.

38. Cramer JA, Roy A, Burrell A, et al. Medication compliance and persistence: terminology and definitions. Value Health. 2008;11(1):44-47.

39. López-González R, León L, Loza E, Redondo M, de Yébenes MJ, Carmona L. Adherence to biologic therapies and associated factors in rheumatoid arthritis, spondyloarthritis and psoriatic arthritis: a systematic literature review. Clin Exp Rheumatol. 2015;33(4):559-569.

40. Lyu R, Govoni M, Ding Q, et al. Treatment persistence among patients with rheumatoid disease (RA, AS, PsA) treated with subcutaneous biologics in Germany. Rheumatol Int. 2016;36(1):143-153.

41. Saad AA, Ashcroft DM, Watson KD, et al. Persistence with anti-tumour necrosis factor therapies in patients with psoriatic arthritis: observational study from the British Society of Rheumatology Biologics Register. Arthritis Res Ther. 2009;11(2):R52.

42. Kristensen LE, Karlsson JA, Englund M, Petersson IF, Saxne T, Geborek P. Presence of peripheral arthritis and male sex predicting continuation of anti-tumor necrosis factor therapy in ankylosing spondylitis: an observational prospective cohort study from the South Swedish arthritis treatment group register. Arthritis Care Res (Hoboken). 2010; 62(10):1362-1369.
43. Favalli EG, Selmi C, Becciolini A, et al. Eight-year retention rate of first-line tumor necrosis factor inhibitors in spondyloarthritis: a multicenter retrospective analysis. Arthritis Care Res (Hoboken). 2017;69(6): 867-874.

44. Renzi C, Di Pietro C, Tabolli S. Participation, satisfaction and knowledge level of patients with cutaneous psoriasis or psoriatic arthritis. Clin Exp Dermatol. 2011;36(8):885-888.

45. Nolla J, Rodríguez M, Martin-Mola E, et al. Patients' and rheumatologists' preferences for the attributes of biological agents used in the treatment of rheumatic diseases in Spain. Patient Prefer Adherence. 2016; 10:1101-1113.

46. Rothery C, Bojke L, Richardson G, et al. A discrete choice experiment to explore patients' willingness to risk disease relapse from treatment withdrawal in psoriatic arthritis. Clin Rheumatol. 2016;35(12):2967-2974.

47. Sokka T, Kautiainen H, Hannonen P, Pincus T. Changes in Health Assessment Questionnaire disability scores over five years in patients with rheumatoid arthritis compared with the general population. Arthritis Rheum. 2006;54(10):3113-3118.

48. van Echteld I, Cieza A, Boonen A, et al. Identification of the most common problems by patients with ankylosing spondylitis using the international classification of functioning, disability and health. J Rheumatol. 2006;33(12):2475-2483.

49. Carter R, Riantawan P, Banham SW, Sturrock RD. An investigation of factors limiting aerobic capacity in patients with ankylosing spondylitis. Respir Med. 1999;93(10):700-708.

50. Ozdemyr O, Inanici F, Hasçelik Z. Reduced vital capacity leads to exercise intolerance in patients with ankylosing spondylitis. Eur JPhys Rehabil Med. 2011;47(3):391-397.

51. Halvorsen S, Vøllestad NK, Fongen C, et al. Physical fitness in patients with ankylosing spondylitis: comparison with population controls. Phys Ther. 2012;92(2):298-309.

52. Marcora S, Casanova F, Williams E, Jones J, Elamanchi R, Lemmey A. Preliminary evidence for cachexia in patients with well-established ankylosing spondylitis. Rheumatology. 2006;45(11):1385-1388.

53. Toussirot E, Michel F, Wendling D. Bone density, ultrasound measurements and body composition in early ankylosing spondylitis. Rheumatology (Oxford). 2001;40(8):882-888.

54. Saad AA, Symmons DPM, Noyce PR, Ashcroft DM. Risks and benefits of tumor necrosis factor- $\alpha$ inhibitors in the management of psoriatic arthritis: systematic review and metaanalysis of randomized controlled trials. J Rheumatol. 2008;35(5):883-890.

55. Curkendall S, Patel V, Gleeson M, Campbell RS, Zagari M, Dubois R. Compliance with biologic therapies for rheumatoid arthritis: so patient out-of-pocket payments matter? Arthritis Rheum. 2008;59(10): $1519-1526$

56. Harley CR, Frytak JR, Tandon N. Treatment compliance and dosage administration among rheumatoid arthritis patients receiving infliximab, etanercept, or methotrexate. Am J Manag Care. 2003;9(6 Suppl):S136-S143.

57. Borah BJ, Huang X, Zarotsky V, Globe D. Trends in RA patients' adherence to subcutaneous anti-TNF therapies and costs. Curr Med Res Opin. 2009;25(6):1365-1377.

58. Calip GS, Adimadhyam S, Xing S, Rincon JC, Lee WJ, Anguiano RH. Medication adherence and persistence over time with self-administered TNF-alpha inhibitors among young adult, middle-aged, and older patients with rheumatologic conditions. Semin Arthritis Rheum. 2017; 47(2): 157-164.

59. Lizán L, Comellas M, Paz S, Poveda JL, Meletiche D, Polanco C. Treatment adherence and other patient-reported outcomes as cost determinants in multiple sclerosis: a review of the literature. Patient Prefer Adherence. 2014;8:1653-1664.

60. van den Bemt BJ, Zwikker HE, van den Ende CH. Medication adherence in patients with rheumatoid arthritis: a critical appraisal of the existing literature. Expert Rev Clin Immunol. 2012;8(4):337-351.

61. Kravitz RL, Melnikow J. Engaging patients in medical decision making. BMJ. 2001;323(7313):584-585.

62. Nota I, Drossaert CH, Taal E, Vonkeman HE, van de Laar MA. Patient participation in decisions about disease modifying anti-rheumatic drugs: a cross-sectional survey. BMC Musculoskelet Disord. 2014;15:333. 
Patient Preference and Adherence

Dovepress

\section{Publish your work in this journal}

Patient Preference and Adherence is an international, peer-reviewed, open access journal that focuses on the growing importance of patient preference and adherence throughout the therapeutic continuum. Patient satisfaction, acceptability, quality of life, compliance, persistence and their role in developing new therapeutic modalities and compounds to optimize

Submit your manuscript here: http://www.dovepress.com/patient-preference-and-acherence-journa clinical outcomes for existing disease states are major areas of interest for the journal. This journal has been accepted for indexing on PubMed Central. The manuscript management system is completely online and includes a very quick and fair peer-review system, which is all easy to use. Visit http://www. dovepress.com/testimonials.php to read real quotes from published authors. 